\title{
LEGALITAS BADAN USAHA MANDIRI TERPADU (BMT) SEBAGAI LEMBAGA KEUANGAN MIKRO BERDASARKAN HUKUM DI INDONESIA
}

\author{
ARI RAHMAD HAKIM BUDIAWAN FIRDAUS ${ }^{1)}$, YUDHI SETIAWAN ${ }^{2)}$, \\ I GUSTI AGUNG WISUDAWAN ${ }^{3)}$
}

Dosen Hukum Bisnis Fakultas Hukum Universitas Mataram

agung.wisudawan@gmail.com

\begin{abstract}
ABSTRAK
Keberadaan Baitul Maal wa Tamwil (BMT) sebagai salah satu lembaga keuangan mikro di Indonesia mempunyai kedudukan dan peranan yang sangat strategis, hal ini tidak berlebihan karena dalam kenyataannya sebagai lembaga keuangan mikro, BMT secara faktual menunjang perekonomian masyarakat, khususnya pengusaha kecil atau mikro dan masyarakat berpenghasilan rendah pada umumnya yang sebagian besar tinggal di pedesaan. Keberadaan BMT yang menyatu dengan kehidupan masyarakat berpenghasilan rendah merupakan salah satu keunggulan tersendiri dari lembaga pembiayaan ini, sehingga lebih memungkinkan masyarakat kecil untuk mengakses pendanaan. Dengan demikian dapat dikatakan bahwa BMT mempunyai kedudukan dan peranan yang sangat penting karena dalam perkembangannya terus meningkat secara signifikan sebagai Lembaga Keuangan Mikro, baik dilihat dari kinerja keuangan dan jumlah nasabah yang tidak dapat dijangkau oleh lembaga perbankan yang ada. Namun dengan keberadaan dan peranan yang penting ini, maka hendaknya bagi setiap BMT untuk memperhatikan aspek legalitas baik kelembagaan dan operasional yang harus ada pada dirinya, sehingga legal keberadaannya dan legal pula segala produk jasa yang ditawarkan serta terjamin penerapan prinsip syariah dalam kegiatannya.
\end{abstract}

Kata kunci : Legalitas, Produk, BMT, Lembaga Keuangan Mikro

\section{ABSTRACT}

The existence of Baitul Maal wa Tamwil (BMT) as a microfinance institution in Indonesia has a very strategic position and role, this is not an exaggeration because in reality as a microfinance institution, BMT supports the community's economy, especially small or micro-entrepreneurs and the community. low-income earners in general who mostly live in rural areas. The existence of BMTs that is integrated with the lives of low-income people is one of the distinct advantages of this financing institution so that it makes it easier for the poor to access funding. Thus it can be said that BMT has a very important position and role because in its development it continues to increase significantly as a Micro Financial Institution, both in terms of financial performance and the number of customers that are not accessible to existing banking institutions. However, with this important existence and role, every BMT should pay attention to both institutional and operational legality aspects that must exist in him, so that the legal existence of all service products offered and guaranteed application of sharia principles in their activities.

Keywords: legality, products, BMT, microfinance institutions

\section{PENDAHULUAN}

Seiring dengan pesatnya perkembangan lembaga keuangan di Indonesia, baik yang kelembagaannya berbentuk lembaga keuangan Bank menggunakan prinsif syariah maupun yang berbentuk lembaga keuangan non-Bank menjadi daya tarik sendiri dan sebagai alternatif pilihan pembiayaan bagi masyarakat selain lembaga keuangan yang menerapkan prinsip atau sistem bunga dalam operasionalnya. Salah satu lembaga keuangan mikro yang progres berkembangnya sangat pesat adalah lembaga keuangan mikro syariah mempunyai peran penting dalam meningkatkan perekonomian masyarakat. Pesatnya peranan Lembaga Keuangan Mikro ini karena hampir 51,2 unit atau 99,9 \% pelaku usaha dalam perekonomian Indonesia didominasi oleh unit usaha mikro dan kecil (Ali Sakti Dalam bukunya Abdul Rasyid, 2017). Lembaga 
Keuangan Mikro bisa dikatakan sebagai salah satu pilar penting dalam proses intermediasi keuangan yang dibutuhkan oleh masyarakat kecil dan menengah guna untuk konsumsi maupun produksi serta juga dalam menyimpan hasil usahanya.

Sebelum lahirnya Undang-Undang Nomor 1 Tahun 2013 tentang Lembaga Keuangan Mikro, Lembaga Keuangan Mikro Syariah (LKMS) di Indonesia dikenal dengan nama Baitul Mal wa Tamwil (BMT) atau Badan Usaha Mandiri Terpadu atau Koperasi Simpan Pinjam dan Pembiayaan Syariah (KSPPS). Lembaga tersebut pada umumnya berbadan hukum. Berdasarkan Undang-Undang Nomor 25 Tahun 1992 tentang Perkoperasian yang secara spesifik diatur dalam Peraturan Menteri Koperasi dan Usaha Kecil Menengah Republik Indonesia Nomor 16/Per/M.KUM/IX/2015 tentang Pelaksanaan Kegiatan Usaha Simpan Pinjam dan Pembiayaan Koperasi, perihal perizinan, pendirian, pengawasan dan pembinaan badan koperasi jenis KSPPS harus dilakukan oleh Pemerintah.

\section{Rumusan Masalah}

Berdasarkan diuraikan pada pendahuluan dalam latar belakang di atas, maka dapat dirumuskan permasalahan yaitu : 1) Apa legalitas yang harus dipenuhi oleh Badan Usaha Mandiri Terpadu (BMT) sebagai lembaga keuangan mikro berdasarkan hukum di Indonesia, 2) Apa produk jasa yang disediakan oleh Badan Usaha Mandiri Terpadu (BMT) dalam pelayanan kepada masyarakat, dan 3) Bagaimana jaminan penerapan prinsip syariah dalam prodak jasa yang ditawarkan kepada masyarakat.

\section{Tujuan Penelitian}

Adapun tujuan penelitian ini sebagai berikut:

1. Untuk mengetahui legalitas yang harus dipenuhi oleh Badan Usaha Mandiri Terpadu (BMT) sebagai lembaga keuangan mikro berdasarkan hukum di Indonesia,

2. Untuk mengetahui produk jasa yang disediakan oleh Badan Usaha Mandiri Terpadu (BMT) dalam pelayanan kepada masyarakat, dan

3. Untuk mengetahui jaminan penerapan prinsip syariah dalam prodak jasa yang ditawarkan kepada masyarakat

\section{METODE PENELITIAN}

Penelitian merupakan penelitian kajian pustaka dengan analisis deksriptif. Penelitian kajian ini berdasarkan kajian-kajian beberapa pendapat atau teori ahli serta konstitusi atau aturan-aturan perundangundangan dan peraturan pemerintah lainnya. Berdasarkan beberapa teori dan peraturan-peraturan tersebut ditarik hasil atau kesimpulan yang kemudian menjadi hasil dari penelitian ini.

\section{HASIL DAN PEMBAHASAN}

\section{Legalitas Badan Usaha Mandiri Terpadu (BMT) sebagai Lembaga Keuangan Mikro Berdasarkan Hukum di Indonesia.}

Peraturan perudang-undangan di Indonesia terdapat bentuk badan usaha yang berbadan hukum yaitu Perseroan Terbatas dan Koperasi termasuk badan usaha yang milik Negara yaitu Perum dan Perseroan. Adapun bentuk usaha yang non berbadan hukum seperti Persekutuan Perdata (Maatchap), Firma dan Persekutuan Komanditer (Comanditer Venootchap) yang pengaturannya masih berdasarkan ketentuan Kitab Undang-Undang Hukum Perdata dan Kitab Undang-Undang Hukum Dagang. Selain yang bentuk usaha yang berupa persekutuan, terdapat juga bentuk usaha perseorangan yang banyak didirikan oleh masyarakat sebagai bentuk usaha seperti Usaha Dagang atau Perusahaan Dagang yang juga belum mendapatkan tempat dalam peraturan perundang-undangan di Indonesia terutama mengenai legalitas dari bentuk usahanya, perusahaan perseorangan ini hanya ditemukan pengaturannya dalam peraturan Menteri saja, sehingga kalau dilihat dari tata urutan peraturan peraturan perundang-undangan di Indonesia, kedudukan dan legalitas dari perusahaan perseorangan ini belum kuat dan belum mendapatkan tempat yang pasti.

Jika dikaji lebih mendalam lagi, usaha perseorangan ini baik Usaha Dagang maupun Perusahaan Dagang, maka dapat dikatakan bahwa usaha tersebut adalah usaha yang berskala mikro, hal ini sesuai dengan Ketentuan Umum Pasal 1 Undang-Undang Nomor 20 Tahun 2008 tentang Usaha Mikro, Kecil dan Menengah (UMKM). Selanjutnya Kententuan Umum Pasal 1 Undang-Undang UMKM memberikan definisi bahwa Usaha Mikro adalah usaha produktif milik orang perorangan dan/atau badan usaha perorangan yang memenuhi kriteria usaha mikro sebagaimana diatur dalam undang-undang ini. Adapun Pasal 6 Undangundang UMKM memberikan kriteria usaha mikro adalah memiliki kekayaan bersih paling banyak 50 juta 
rupiah (tidak termasuk tanah dan bangunan tempat usaha) atau memiliki hasil penjualan tahunan paling banyak adalah 300 juta rupiah. Namun dalam Undang-Undang UMKM ini tidak terdapat ketentuan yang berkaitan dengan legalitas bentuk usaha dari usaha mikro ini, tetapi hanya menentukan kriteria dari usaha mikro itu sendiri sebagaimana yang disebutkan dalam ketentuan Pasal 6 di atas.

Jika diteliti secara saksama dalam ketentuan Peraturan Pelaksana Undang-Undang Usaha Mikro Kecil dan Menengah Nomor 17 Tahun 2013 disebutkan bahwa untuk usaha mikro harus memiliki izin usaha sebagai bukti tertulis yang diterbitkan dan dikeluarkan oleh pejabat yang berwenang berdasarkan ketentuan peraturan perundang-undangan sebagai bukti legalitas yang menyatakan sah suatu kegiatan usaha termasuk Usaha Mikro, Usaha Kecil, Usaha Menengah serta telah memenuhi persyaratan dan diperbolehkan untuk menjalankan suatu kegiatan usaha tertentu sesuai dengan bidang usaha yang dilakukan. Namun pernyataan tentang bukti legalitas dalam hal ini pastilah terkait dengan legalitas pendirian suatu kegiatan usaha.

Lebih lanjut Pasal 36 Peraturan Pemerintah tentang UMKM ditentukan bahwa bukti legalitas yang diminta dan harus dipenuhi adalah berupa : a) Surat Ijin Usaha; b) tanda bukti pendaftaran; c) tanda bukti pendataan. Namun dalam praktek kegiatan pendirian usaha perseorangan hanya diminta tanda bukti pendaftaran dan tanda bukti pendataan saja sebagai bentuk atau wujud dari legalitas usaha. Sedangkan tata cara perijinan yang dimaksud tersebut merupakan tata cara perijinan yang diatur dalam ketentuan peraturan perundang-undangan yang sudah ada yaitu peraturan yang mengatur tentang legalitas pendirian usaha yang berskala mikro atau usaha perseorangan.

Selanjutnya ada beberapa bentuk dari legalitas badan usaha atau perusahaan :

a. Nama Badan Usaha atau Perusahaan.

Hukum positif di Indonesia tidak mengatur secara khusus tentang nama perusahaan, namun Negara Indonesia memiliki Undang-Undang tentang penggunaan nama Perseroan Terbatas yaitu melalui UndangUndang Nomor 26 Tahun 1998. Selain itu kita juga mempunyai Undang-Undang Nomor 15 Tahun 2001 tentang Merek sebagaimana telah dirubah dengan Undang-Undang Nomor 20 Tahun 2016 Tentang Merek dan Indikasi Geografis, dalam undang-undang merek ini pada prinsifnya diatur tentang larangan menggunakan merek terdaftar milik orang lain sebagai nama perusahaan. Kebebasan setiap orang untuk memilih dan menggunakan nama perusahaan disesuaikan dan harus berdasarkan asas yang berlaku yaitu selama tidak dilarang oleh Undang-undang yang mengaturnya dan tidak bertentangan dengan ketertiban umum serta tidak bertentangan dengan kesusilaan.

b. Merek Badan Usaha atau Perusahaan.

Berdasarkan Ketentuan Umum Pasal 1 Undang-Undang Nomor 20 Tahun 2016 tentang Merek dan Indikasi Geografis memberikan pengertian secara normatif tentang merek. Merek adalah tanda yang dapat ditampilkan secara grafis berupa gambar, logo, nama, kata, huruf, angka, susunan warna, dalam bentuk 2 (dua) dimensi dan/atau 3 (tiga) dimensi, suara, hologram, atau kombinasi dari 2 (dua) atau lebih unsur tersebut untuk membedakan barang dan/atau jasa yang diproduksi oleh orang atau badan hukum dalam kegiatan perdagangan barang dan/atau jasa. Pada prinsipnya dan dalam praktek penggunaan nama perusahaan, biasanya nama perusahaan atau badan usaha ini sekaligus dijadikan sebagai merek produk barang ataupun jasa dari perusahaan tersebut.

c. Akta Pendirian.

Salah satu bentuk dari legalitas badan usaha atau perusahaan adalah adanya akta pendirian yang dibuat oleh dan dihadapan notaries sebagai pejabat umum yang mendapat wewenang dari pemerintah dalam hal ini Kementerian Hukum dan Hak Asasi Manusia untuk mengesahkan dan menyaksikan surat perjanjian, surat wasiat, akta-akta dan lain sebagainya. Dalam akta pendirian tersebut juga memuat anggaran dasar perusahaan yaitu seperangkat peraturan yang menjadi dasar berdiri dan beroperasinya perusahaan menurut hukum yang berlaku.

d. Nomor Pokok Wajib Pajak (NPWP).

NPWP merupakan suatu sarana dalam administrasi perpajakan yang digunakan sebagai tanda pengenal diri atau indentitas bagi wajib pajak. Setiap wajib pajak hanya memiliki satu NPWP, terhadap wajib pajak yang tidak mendaftarkan diri untuk memperoleh NPWP dikenakan sanksi sesuai dengan ketentuan peraturan perundang-undangan perpajakan yang berlaku.

e. Surat Izin Usaha Perdagangan (SIUP).

Sebelum perusahaan atau badan usaha menjalankan sebuah usaha, terlebih dahulu harus mengurus perizinan usaha, salah satunya adalah Surat Izin Usaha Perdagangan (SIUP). SIUP ini mutlak dimiliki demi kelancaran kegiatan operasional perusahaan kedepannya. Surat Izin Usaha Perdagangan ini merupakan salah satu legalitas dan jati diri yang dipakai oleh badan usaha atau perusahaan untuk menjalankan usahanya secara legal (sah) di wilayah Negara Kesatuan Republik Indonesia apapun jenis dan bidang usahanya baik dibidang produksi barang maupun dibidang jasa. 
Dalam Pasal 2 ayat 1 sampai ayat 3 Peraturan Menteri Perdagangan Nomor 46/M-DAG/PER/9/2009 tentang penerbitan Surat Izin Usaha Perdagangan (SIUP) menerangkan bahwa : "setiap perusahaan wajib memiliki SIUP, SIUP terdiri dari SIUP Kecil, SIUP Menengah dan SIUP Besar, selain SIUP tersebut dapat juga diberikan SIUP Mikro kepada perusahaan perdagangan mikro".

Selanjutnya menurut Pasal 3 Peraturan Menteri Perdagangan Nomor 46/M-DAG/PER/9/2009 menggolongkan SIUP menjadi SIUP Kecil, Menengah dan Besar adalah :

1. SIUP kecil wajib dimiliki oleh perusahaan perdagangan yang kekayaan bersihnya lebih dari $\mathrm{Rp}$. 50.000.000,- (lima puluh juta rupiah) sampai dengan paling banyak Rp. 500.000.000,- (lima ratus juta rupiah) tidak termasuk tanah dan tempat usaha;

2. SIUP menengah wajib dimiliki oleh perusahaan perdagangan yang kekayaan bersihnya lebih dari Rp. 500.000.000,- (lima ratus juta rupiah) sampai dengan paling banyak Rp. 10.000.000.000,- (sepuluh milyar rupiah) tidak termasuk tanah dan bangunan tempat usaha;

3. SIUP besar wajib dimiliki oleh perusahaan perdagangan yang kekayaan bersihnya lebih dari Rp. 10.000.000.000,- (sepuluh milyar rupiah) tidak termasuk tanah dan bangunan tempat usaha.

f. Surat Izin Tempat Usaha (SITU).

Surat izin Tempat Usaha (SITU) adalah surat izin yang diberikan kepada setiap pengusaha yang mendirikan tempat usaha maupun menempati tempat usaha yang disediakan oleh pemerintah dalam melakukan usaha yang dilaksanakan secara teratur dalam bidang tertentu dengan maksud mencari keuntungan atau laba. Peraturan mengenai izin tempat usaha ini berberda antara daerah yang satu dengan daerah yang lain karena diatur dengan Peraturan Daerah (PERDA) di masing-masing Kabupaten dan Kota sesuai dengan otonomi daerah, namun secara umum persyaratan untuk kelengkapan surat izin ini antara satu daerah dengan daerah yang lain pada dasar adalah sama.

g. Tanda Daftar Perusahaan (TDP).

Tanda Daftar Perusahaan (TDP) merupakan daftar pencatatan resmi yang diadakan berdasarkan ketentuan undang-undang atau peraturan lain yang berkaitan dengan pelaksanaan undang-undang daftar perusahaan yaitu sesuai dengan Undang-Undang Nomor 3 Tahun 1982 yang membahas tentang Wajib Daftar Perusahaan. Kepemilikan TDP akan menjadi penanda (identitas) segala aktivitas yang sedang berjalan disuatu perusahaan, artinya TDP ini menjadi dokumen resmi yang menunjukan profil perusahaan secara lengkap. Selain itu juga TDP ini memuat catatan dan juga memuat sejumlah keterangan yang wajib didaftarkan oleh setiap perusahaan dan untuk mendapatkan pengesahan (legalisasi) dari pejabat yang berwenang. Jadi dengan demikian setiap badan usaha, baik yang berbentuk Perseroan Terbatas, Persekutuan Komanditer (CV), Firma, Koperasi, Yayasan hingga usaha perseorangan wajib mendaftarkan badan usaha yang dimilikinya. Termasuk didalamnya adalah kantor cabang, anak perusahaan, kantor pembantu, kantor wilayah hingga agen yang masih beroperasi di bawah nama perusahaan tersebut.

Selain diatur dalam Undang-Undang Nomor 3 Tahun 1982 tentang Wajib Daftar Perusahaan, kewajiban pengusaha mendaftarkan badan usaha yang dikelolanya juga diatur dalam Peraturan Menteri Perdagangan Nomor 37/M-DAG/PER/2007 mengenai penyelenggaraan Perusahaan juncto Keputusan Presiden Nomor 53 Tahun 1998 mengenai usaha atau kegiatan yang tidak dikenakan Wajib Daftar Perusahaan.

h. Analisis Dampak Lingkungan (AMDAL).

Analisis Dampak Lingkungan adalah pembahasan mengenai dampak suatu usaha dan/atau kegiatan yang direncanakan pada lingkungan yang diperlukan bagi proses pengembalian keputusan tentang penyelenggaraan usaha dan/atau kegiatan di Indonesia. AMDAL ini dibuat saat suatu perencanaan proyek yang diperkirakan akan memberikan pengaruh terhadap lingkungan hidup di sekitarnya. Dasar hukum AMDAL di Indonesia atau yang berlaku secara normative adalah Peraturan Pemerintah Nomor 27 Tahun 2012 tentang Izin Lingkungan Hidup yang merupakan pengganti dari Peraturan Pemerintah Nomor 27 Tahun 1999 tentang Analisis Dampak Lingkungan.

Secara umum dapat digambarkan bahwa ada 6 (enam) tahapan terkait dengan legalitas sebuah usaha, hal ini sangat penting terutama bagi setiap usaha yang didirikan baik yang berbentuk badan hukum maupun yang bentuknya non badan hukum yaitu :

a. Klasifikasi bidang usaha yang sesuai. Klasifikasi bidang usaha ini sangat penting karena akan mencerminkan fokus kegiatan usaha para pelaku usaha secara spesifik, misalnya usaha bidang jasa (apakah jasa keuangan ataukah bidang produksi dan seterusnya);

b. Memilih badan usaha yang sesuai. Sebagaimana yang telah di uraikan pada bagian sebelumnya di atas bahwa ada beberapa jenis badan usaha seperti usaha perseorangan, usaha yang bentuk perserikatan baik yang berbadan hukum seperti Perseroan Terbatas dan Koperasi maupun yang non berbadan hokum seperti Perserikatan Perdata (maatchap), Firma dan Persekutuan Komanditer (CV); 
c. Mendirikan badan usaha. Dalam tahap ini, pelaku usaha membuat akta notaries untuk mendirikan badan usaha (baik perseorangan, maatchap, firma, persekutuan komanditer, Perseroan Terbatas ataupun Koperasi. Untuk badan usaha yang berbadan hukum seperti Perseroan Terbatas, akta pendiriannya harus mendapat pengesahan dari Menteri Hukum dan HAM RI, sedangkan badan hukum Koperasi harus mendapatkan pengesahan dari Dinas Koperasi setempat atau Menteri Koperasi dan UKM Republik Indonesia;

d. Membuat Nomor Pokok Wajib Pajak Perusahaan. Setiap pelaku usaha sesuai dengan peraturan yang ada diwajibkan membuat Nomor Pokok Wajib Pajak Perusahaan. Saat ini dalam praktek pendirian sebuah usaha dipersyaratkan untuk memiliki alamat tempat usaha yang jelas sesuai rencana zonasi daerah, kota dan peruntukan kegiatannya. Di beberapa kota melarang kegiatan usaha tertentu dilakukan di zona perumahan seperti usaha restoran, karoke dan travel agent;

e. Mengurus perijinan usaha. Setiap kegiatan usaha pada prinsipnya dipersyaratkan adanya ijin operasional kecuali untuk usaha yang ditentukan tidak wajib ijin operasional. Ijin operasional ini diperlukan dalam rangka untuk melaksanakan kegiatan usaha secara legal dan formal;

f. Mendaftarkan karyawan sebagai peserta BPJS. Setiap badan usaha pada dasarnya diwajibkan untuk mengikutsertakan para karyawannya menjadi anggota BPJS hal ini biasanya sebagai salah satu cara untuk memberikan kepastian akan adanya jaminan kesehatan bagi karyawan dan bagi badan usaha sebagai persyaratan untuk mendapatkan izin usaha.

Selanjutnya dalam Undang-Undang Nomor 28 Tahun 2009 Tentang Pajak Daerah dan Retribusi Daerah telah dijelaskan bahwa dalam mengurus Surat Izin Usaha Perdagangan (SIUP), Izin Usaha Industri (IUI), Izin Usaha Jasa Konstruksi (IUJK), Tanda Daftar Industri (TDI), Tanda Daftar Gudang (TDG), Izin Perluasan, Izin Pariwisata, Izin Lokasi dan Tanda Daftar Perusahaan (TDP) itu sebenarnya adalah bebas retribusi atau tidak dipungut biaya. Dengan terpenuhinya berbagai persyaratan administratif dan berbagai perizinan yang menjadi legalitas sebuah usaha di atas, maka secara hukum sebuah usaha yang ada dapat secara sah beroperasi di wilayah Negara Kesatuan Republik Indonesia.

Namun demikian ada berbagai kelengkapan untuk legalitas usaha yang berlaku di Indonesia yaitu :

a. Surat Keterangan Domisili Usaha (SKDU). Merupakan salah satu kelengkapan legalitas usaha yang dikeluarkan oleh Kantor Kelurahan/Desa ataupun Kantor Kecamatan dimana usaha tersebut didirikan. Surat atau dokumen ini biasanya dibuat sebagai syarat untuk mengurus berbagai dokumen lain yang terkait dengan pendirian sebuah badan usaha seperti SIUP, NPWP, TDP dan lain sebagainya.

b. Nomor Pokok Wajib Pajak (NPWP). Adalah nomor yang diberikan kepada orang atau badan wajib pajak yang dikeluarkan oleh Kantor Pelayanan Pajak setempat yang dilakukan berdasarkan permohonan sebagai sarana administrasi perpajakan yang dipergunakan sebagai tanda pengenal identitas wajib pajak guna melaksanakan hak dan kewajiban dalam hal perpajakan.

c. Surat Izin Usaha Dagang (UD). Adalah surat izin usaha perseorangan yang bisa didapat dengan mengajukan permohonan izin usaha di Kantor Wilayah Departemen Perindustrian dan Perdagangan di wilayah tempat tinggal usaha.

d. Surat Izin Tempat Usaha (SITU). Merupakan surat izin yang diberikan kepada perorangan, perusahaan ataupun badan usaha guna mendapatkan izin tempat usaha sesuai tata ruang wilayah dalam rangka penanaman modal. Surat izin ini dikeluarkan oleh Pemerintah Daerah dan masa berlakunya paling lama tiga tahun dan apabila masa berlakunya sudah berakhir maka dapat dimohonkan untuk diperpanjang dengan memenuhi syarat-syarat yang berlaku.

e. Surat Izin Prinsip. Merupakan surat izin atau dokumen yang dikeluarkan oleh Pemerintah Daerah (Kabupaten/Kota) kepada badan usaha yang akan melakukan kegiatan usaha di suatu daerah. Dokumen ini memberikan kepastian hokum dalam kegiatan berinvestasi dan meningkatkan sumber-sumber pendapatan daerah (Kabupaten/Kota) secara langsung.

f. Surat Izin Usaha Industri (SIUI). Adalah surat izin usaha yang diperuntukan bagi Usaha Kecil dan Menengah untuk mendukung usaha yang bergerak dalam bidang industry. Dokumen atau surat ini didapatkan degan terlebih dahulu mengajukan permohonan ke Kantor Pelayanan Perizinan Terpadu (KPPT) di daerah masing-masing Kabupaten/Kota.

g. Surat Izin Usaha Perdagangan (SIUP). Merupakan surat atau dokumen yang dikeluarkan oleh Pemerintah Daerah (Kabupaten/Kota) untuk melaksanakan kegiatan perdagangan. Setiap perusahaan yang melakukan kegiatan perdagangan wajib memperoleh SIUP ini. SIUP ini terdiri dari tiga kategori yaitu SIUP Kecil, SIUP Menengah dan SIUP Besar tergantung pada criteria banyaknya modal usaha yang dimiliki oleh setiap usaha yang didirikan.

Sementara kalau dikaji berdasarkan Undang-Undang Nomor 3 Tahun 1982 tentang Wajib Daftar Perusahaan membedakan antara perusahaan dengan pengusaha. Perusahaan adalah setiap bentuk usaha yang menjalankan setiap jenis usaha yang bersifat tetap dan terus menerus dan yang didirikan, bekerja serta 
berkedudukan dalam wilayah Republik Indonesia untuk tujuan memperoleh keuntungan dan atau laba. Sementara pengusaha adalah setiap orang perorangan atau persekutuan atau badan hokuantara yang dimaksudm yang menjalankan suatu jenis perusahaan. Kewajiban untuk melakukan pendaftaran dibebankan pada setiap perusahaan. Sedangkan definisi perusahaan itu sendiri tidak menjelaskan apakah perusahaan perseorangan ataukah yang bentuknya persekutuan.

Namun demikian dapat dibaca ketentuan Pasal 8 Undang-Undang Wajib Daftar Perusahaan bahwa yang wajib melakukan pendaftaran adalah badan hukum termasuk Perseroan Terbatas, Koperasi, persekutuan, perorangan dan perusahaan lain. Undang-Undang ini memisahkan antara apa yang dimaksud dengan Perusahaan Perseorangan dengan Perusahaan Kecil Perorangan. Selanjutnya pada Pasal 6 ayat (1) b disebutkan bahwa; "Setiap perusahaan kecil perorangan yang dijalankan oleh pribadi pengusahanya sendiri atau dengan mempekerjakan hanya anggota keluarganya sendiri yang terdekat serta tidak memerlukan izin usaha dan tidak merupakan suatu badan hukum atau suatu persekutuan. Artinya dapat dikatakan bahwa dari pengertian dan ketentuan pasal yang mengatur tentang perusahaan kecil perorangan dalam Undang-Undang Wajib Daftar Perusahaan tidak mewajibkan perusahaan kecil perorangan untuk melakukan daftar perusahaan.

Sementara kalau Badan Usaha Mandiri Terpadu (BMT) karena bentuknya wajib berbadan hukum dan biasanya dalam praktek berbentuk badan hukum Koperasi dan memerlukan izin usaha dalam operasionalnya apalagi jenis atau bidang usaha yang bergerak dalam bidang simpan pinjam ataupun koperasi serba usaha (KSU), maka dapat dikatakan bahwa secara hukum yang berlaku di Indonesia dan berdarakan wawancara dengan Aminullah, SH, MH Sekretaris Badan Usaha Mandiri Terpadu (BMT) Al-Hamasah Kotaraja Lombok Timur, maka Badan Usaha Mandiri Terpadu (BMT) tersebut wajib mempunyai Tanda Daftar Perusahaan (TDP).

Dengan demikian agar sebuah Badan Usaha Mandiri Terpadu (BMT) memenuhi legalitasnya sebagai lembaga keuangan mikro, maka bagi setiap Badan Usaha Mandiri Terpadu (BMT) wajib memiliki beberapa hal sebagai perwujudan legalitasnya yaitu :

Pertama, berbentuk Badan Hukum, baik badan hukum Perseroan Terbatas (PT) maupun berbentuk Koperasi dengan mengikuti prosedur dan memenuhi persyaratan yang ditentukan dalam Undang-Undang Perseroan Terbatas bagi Badan Usaha Mandiri Terpadu (BMT) yang didirikan dalam bentuk Perseroan Terbatas (PT) dan mengikuti prosedur serta persyaratan Undang-Undang Koperasi bagi Badan Usaha Mandiri Terpadu (BMT) yang didirikan dalam bentuk badan hukum Koperasi. Khusus bagi BMT sesuai dengan aturan yang berlaku dalam struktur organnya jika berbentuk Perseroan Terbatas (PT) disamping adanya organ Rapat Umum Pemegang Saham (RUPS), Direksi dan Komisaris serta ditambah/dilengkapi pula dengan organ Dewan Pengawas Syariah (DPS) yang bertugas mengawasi kegiatan PT apakah sesuai dengan prinsif syariah. Demikian juga pada Koperasi yang bergerak dalam bidang simpan pinjam syariah disamping ada Rapat Anggota, Pengurus, Pengawas dan dilengkapi pula dengan organ Dewan Pengawas Syariah.

Kedua, Badan Usaha Mandiri Terpadu (BMT) wajib memiliki Akta Pendirian yang dibuat dan dihadapan Notaris atau dalam bentuk Akta Notaris. Akta Notaris ini secara teori disebut dengan akta autentik, dimana akta ini merupakan akta pendirian BMT yang substansi muatan materinya merupakan kesepakatan para pihak yang membuatnya. Akta pendirian ini sekaligus sebagai Anggaran Dasar/Anggaran Rumah Tangga BMT diantaranya berisi mulai dari nama para pihak yang mendirikan, nama BMT, kewajiban dan hak para anggota pendiri, organ BMT, bidang usaha, jangka waktu berdiri BMT, termasuk diatur juga cara penyelesaian sengketa diantara para pendiri.

Ketiga, Badan Usaha Mandiri Terpadu (BMT) wajib memiliki izin usaha dari instansi terkait, baik BMT serba usaha ataupun yang bergerak dalam bidang usaha simpan pinjam. Untuk BMT yang bidang usahanya bergerak dalam bidang simpan pinjam, maka harus memperoleh izin usaha simpan pinjam dari Dinas Koperasi setempat, hal ini sebagai persyaratan izin operasional usaha agar legal dan agar konsumen terlindungi dari praktek usaha yang curang atau tidak sehat.

Keempat, Badan Usaha Mandiri Terpadu (BMT) wajib memiliki Nomor Pokok Wajib Pajak ini merupakan identitas yang diberikan oleh Kantor Pajak terhadap wajib pajak. Dengan demikian apabila BMT ini sebagai badan usaha yang berbadan hukum, maka secara otomatis akan menjadi subyek hukum yang dapat dikategorikan wajib pajak.

Kelima, Badan Usaha Mandiri Terpadu (BMT) wajib memiliki Tanda Daftar Perusahaan (TDP), hal ini sesuai dengan ketentuan perundang-undangan yang berlaku di Indonesia yaitu setiap kegiatan usaha yang melakukan kegiatan usaha di wilayah Negara Kesatuan Republik Indonesia, kecuali bagi kegiatan usaha yang dikecualikan, diwajibkan untuk memiliki Tanda Daftar Perusahaan sebagai wujud atau bentuk dari legalitas dari sebuah badan usaha atau perusahaan. 


\section{Produk Jasa Badan Usaha Mandiri Terpadu (BMT) dalam Pelayanan Kepada Masyarakat.}

Badan Usaha Mandiri Terpadu (Baitul Maal Wat Tamwil/BMT) merupakan Badan Usaha yang berbadan hukum pada umumnya berbentuk Koperasi dengan bidang usaha yang dapat meliputi Koperasi Serba Usaha maupun simpan pinjam dengan pola atau sistem syariah. Sistem operasional BMT pada prinsipnya terilhami oleh prinsip syariah yang dipraktekkan oleh Bank Muamalat Indonesia dan dalam kegaitannya juga sering mendapatkan pelatihan-pelatihan dari Pusat Inkubasi Bisnis Usaha Kecil (PINBUK) dan lembaga-lembaga professional baik di dalam maupun luar daerah.

Badan Usaha Mandiri Terpadu (Baitul Maal Wat Tamwil/BMT) menghimpun dana dari anggota dan calon anggota atau masyarakat dengan akad wadi'ah atau mudharobah, qirodh atau qord. Sedangkan dalam kegiatan usaha pinjaman atau pembiayaan dengan menggunakan salah satu diantara beberapa kegiatan seperti akad mudhorabah atau qirodh, musyarakah atau syirkah, murabahah, bai'bitsaman ajil dan qord hasan. Dalam mu'amalah system atau pola syariah tidak menggunakan system bunga, tetapi menggunakan imbalan bagi hasil untuk mudhorabah dan musyarakah atau imbalan laba untuk murobahah dan bai'bitsaman ajil, sedangkan qord hasan biasanya untuk kegiatan yang bersifat sosial (nirlaba). Dengan demikian, maka sesuai dengan istilah Baitul Mal Wat Tamwil (BMT) yang terdiri dari dua istilah yaitu baitul mal yang lebih mengarah pada usaha-usaha pengumpulan dan penyaluran dana yang non profit seperti zakat, infak dan shodaqoh. Sedangkan baitul tamwil yaitu sebagai usaha pengumpulan dan penyaluran dana yang bersifat profit atau komersil.

Dalam pembiayaan, fungsi dan layanan Badan Usaha Mandiri Terpadu (Baitul Maal Wat Tamwil/BMT) tidak berbeda dengan Bank Syariah. BMT juga menjadi penyandang dana bagi pengusaha yang datang kepadanya untuk mengajukan permohonan dana. Besar kecil dana dalam permohonan pengusaha itu pada akhirnya mendapatkan ketetapannya dari pihak BMT sesuai dengan kemampuan financial yang dimilikinya. Secara umum ada beberapa jenis layanan produk jasa BMT sebagaimana diurikan sebelumnya pada prinsip tidak berbeda dari jenis layanan produk jasa bank syariah yang dapat dibagi menjadi 3 (tiga) jenis layanan prodak jasa yaitu :

1. Sistem Jual Beli

a. Ba'i Bitsaman Ajil.

Merupakan penjualan barang kepada anggota dengan mengambil keuntungan (margin) yang diketahui dan disepakati bersama, pembayaran dilakukan dengan cara mengangsur.

b. Murobahah.

Penjualan barang kepada anggota dengan mengambil keuntungan (margin) yang diketahui dan disepakati bersama, pembayaran dilakukan dengan cara jatuh tempo atau sekaligus.

c. Ba'i As-Salam.

Penjualan hasil produksi (komoditi) yang terlebih dahulu dipesan anggota dengan kriteria tertentu yang sudah umum. Anggota harus membayar uang muka kemudian barang dikirim belakangan (setelah jadi).

d. Jual Beli Istisna'.

Penjualan hasil produksi (komoditi) pesanan yang didasarkan kriteria tertentu (yang tidak umum) anggota boleh membayar pesanan ketika masih dalam proses pembuatan/setelah barang itu jadi dengan cara sekjaligus atau mengangsur.

e. Ijaroh.

Pembelian suatu barang yang dilakukan dengan cara sewa terlebih dahulu setelah masa sewa habis maka anggota membeli barang sewa tersebut (Kuntowijoyo, 2001:102).

2. Sistem Bagi Hasil

a. Musyarokah.

Kerjasama penyertaan modal dan masing-masing menentukan jumlahnya sesuai kesepakatan bersama yang digunakan untuk mengelola suatu usaha atau proyek tertentu. Pada prinsipnya dalam pembiayaan musyarokah tidak ada jaminan, namun untuk menghindari terjadinya penyimpangan, Lembaga Keuangan Syariah dapat meminta jaminan. Kerugian harus dibagi antara para anggota secara proporsional menurut saham masing-masing dalam modal.

Partisifasi para mitra dalam pekerjaan merupakan dasar pelaksanaan musyarokah akan tetapi kesamaan porsi kerja bukanlah merupakan syarat. Seorang mitra boleh melaksanakan kerja lebih banyak dan lainnya dalam hal ini ia boleh menuntut bagian keuntungan tambahan bagi dirinya. Hal ini dapat dijadikan dasar dalam penentuan nisbah dimana anggota BMT sebagai pengelola usaha mendapatkan porsi yang lebih tinggi.

b. Mudharabah.

Pemberian modal kepada anggota yang mempunyai skill untuk mengelola usaha atau proyek yang dimilikinya. Pembagian bagi hasil usaha ditentukan berdasarkan kesepakatan. Modal $100 \%$ dari 
shohibul maal, tidak terdapat jadwal angsuran, bagi hasil tidak ditetapkan dimuka dan sifatnya tidak tetap, tergantung fluktuasi keuntungan yang diperoleh. BMT sebagai penyandang dana menanggung semua kerugian akibat dari mudharabah kecuali jika mudharib atau anggota melalukan kesalahan yang disengaja, lalai atau menyalahai perjanjian. Dalam akad ini biaya operasional dibebankan kepada mudharib (Kuntowijoyo, 2001: 170-171).

3. Sistem Jasa.

a. Qord.

Pemberian pinjaman untuk kebutuhan mendesak dan buka bersifat konsumtif. Pengembalin pinjaman sesuai dengan jumlah yang ditentukan dengan cara angsur atau tunai. Contohnya untuk biaya rumah sakit, biaya pendidikan, biaya tenaga kerja.

b. Al-Wakalah.

Pemberian untuk melaksankn urusan dengan batas kewenangan dan waktu tertentu. Penerima kuasa mendapat imbalan yang ditentkan dan disepakati bersama.

c. Al-Hawalah.

Penerimaan pengalihan utang atau piutang dari pihak lain untuk kebutuhan mendesak dn bukan bersifat konsumtif. BMT sebagai penerima pengalihan hutang atau piutang akan mendapatkan fee dari pengaturan pengalihan (management fee).

d. Rahn.

Pinjaman dengan cara menggadaikan barang sebagai jaminan utang dengan membayar jatuh tempo. Ongkos dan biaya penyimpann barang (marhun) ditanggung oleh penggadai (rahin). Barang jaminan adalah milik sendiri (rahin), untuk itu hendaknya rahin bersedia mengisi surat pernyataan kemilikan.

e. Kafalah.

Pemberian garansi kepada anggota yang akan mendapatkan pembiayaan (pelaksanaan suatu usaha atau proyek) dari pihak lain. BMT mendapatkan fee dari anggota sesuai dengan kesepakatan bersama (Kuntowijoyo, 2001: 171-174).

Berdasarkan pada fakta layanan yang diberikan oleh bank syariah belum dapat menjangkau sektor ekonomi riil secara optimal. Kondisi seperti inilah yang menjadi faktor menyebab memunculkan ide dan menjadi latar belakang berdirinya lembaga keuangan mikro seperti BMT Al-Hamasah Kotaraja Lombok Timur.

BMT Al-Hamasah Kotaraja Lombok Timur dalam operasional usahanya pada dasarnya mirip dengan perbankan yaitu melakukan kegiatan penghimpunan dana dari masyarakat dalam bentuk simpanan dan menyalurkan dana kepada masyarakat yang membutuhkan dalam bentuk pembiayaan, serta memberikan jasa-jasa yang dibutuhkan oleh masyarakat. Secara umum produk jasa BMT Al-Hamasah Kotaraja Lombok Timur dalam rangka melaksanakan fungsinya tersebut dapat diklasifikasikan menjadi beberapa produk jasa yaitu : produk penghimpunan dana (funding); produk penyaluran dana (lending) dan produk layanan. Sedangkan untuk produk sosial, BMT Al-Hamasah mempuyai produk yaitu zakat, infaq, shadoqah dan wakaf (Wawancara dengan Aminullah, SH, MH Sekretaris BMT Al-Hamasah, tanggal 22 Oktober 2020).

Dalam operasionalnya BMT Al-Hamasah menggunakan akad wadiah ad dhamanah dalam produk simpanannya, sehingga dapat menggunakan dana yang disimpan oleh nasabah untuk kegiatan produktif. Hal ini juga dapat mendatangkan keuntungan bagi nasabah, yakni bahwa nasabah dimungkinkan mendapatkan bagi hasil yang besarnya tergantung pada kebijakan BMT Al-Hamasah dan tidak boleh diperjanjikan dimuka (depan). Melalui simpanan wadiah nasabah BMT Al-Hamasah terhindar dari risiko kerugian, akan tetapi potensi penghasilan atau keuntungan yang akan diperoleh juga kecil karena sangat tergantung pada kebijakan dari BMT Al-Hamasah yang bersangkutan. Dalam hal nasabah BMT Al-Hamasah menghendaki uang yang disimpan juga memberikan tambahan pendapatan atau memang ditujukan sebagai sarana investasi, maka BMT Al-Hamasah biasanya juga menyediakan produk simpanan yang didasarkan pada akad mudharabah. Melalui simpanan mudharabah nasabah berpeluang mendapatkan penghasilan yang besarnya sesuai dengan nisbah bagi hasil yang telah diperjanjikan diawal akad. Namun demikian nasabah yang memakai skema simpanan mudharabah juga menanggung risiko kerugian atas uang yang disimpan (Wawancara, Aminullah, SH, MH, tanggal 20 Oktober 2020).

Selanjutnya produk penghimpunan dana yang disediakan oleh BMT Al-Hamasah kepada masyarakat dalam meningkatkan mobilitas kegiatan usahanya didasarkan pada akad-akad tradisional Islam, yakni akad jual beli, akad sewa menyewa, akad bagi hasil dan akad pinjam meminjam. Berikutnya akan diuraikan produk jasa dari BMT Al-Hamasah sebagai berikut :

a. Jual Beli.

Jual beli pada prinsipnya adalah akad antara penjual dan pembeli untuk melakukan transaksi jual beli, dimana obyeknya adalah barang dan harga. Adapun penerapan dari akad jual beli ini dalam transaksi BMT Al-Hidayah tampak dalam produk pembiayaan murabahah, salam dan istishna. Dengan demikian akad jual 
beli hanya dapat diterapkan pada produk perbankan berupa penyaluran dana. Adapun bentuk penyaluran dana yang dilakukan oleh BMT Al-Hamasah adalah :

1) Murabahah, adalah jual beli barang sebesar harga produk barang ditambah dengan margin keuntungan yang disepakati.

2) Salam, adalah jual beli barang dengan cara pemesanan dengan syarat-syarat tertentu dan pembayaran tunai terlebih dahulu secara penuh.

3) Istishna, adalah jual beli barang dalam bentuk pemesanan pembuatan barang dengan kriteria dan persyaratan tertentu yang disepakati dengan pembayaran sesuai dengan kesepakatan.

b. Bagi Hasil.

Penerapan akad bagi hasil dalam transaksi di BMT Al-Hamasah inilah yang lebih dikenal di masyarakat karena memang fungsinya sebagai pengganti bunga. Akad ini unik, karena dalam praktek BMT Al-Hamasah menerapkan dalam dua sesi sekaligus, yakni sisi penghimpunan dana (funding) dan sisi penyaluran dana (lending). Pelaksanaan akad bagi hasil dalam produk BMT Al-Hamasah di bidang penghimpunan dana sebagaimana tersebut di atas dalam bentuk simpanan, sedangkan implementasinya dalam bentuk produk penyaluran dana adalah produk pembiayaan mudharabah dan pembiayaan musyarakah.

c. Pinjam Meminjam.

Pinjam meminjam yang bersifat sosial dalam sistem konvensional, produk penyaluran dana berupa kredit merupakan perjanjian pinjam meminjam dengan ketentuan bahwa nasabah debitur wajib membyar bunga berdasarkan presentase tertentu terhadap produk pinjaman. Ini merupakan praktik riba yang dilarang oleh Islam, dalam Islam Akad pinjam meminjam juga disediakan tetapi hanya pada keadaan darurat (emergency), artinya bahwa pinjaman akan diberikan hanya kepada nasabah yang benar-benar membutuhkan uang.

Berdasarkan apa yang telah diuraikan di atas, bahwa BMT Al-Hamasah sebagai lembaga keuangan mikro syariah mempunyai berbagai produk jasa dan berperan sebagai lembaga penghimpun dana dari masyarakat yang mempunyai dana surplus dan untuk menyalurkannya kembali kepada masyarakat yang membutuhkan sebagai solusi atas kesulitan pembiayaan yang dihadapinya. Untuk itu dapat dikatakan bahwa BMT Al-Hamasah adalah lembaga keuangan mikro syariah yang memiliki dua fungsi, yaitu fungsi sosial dan fungsi bisnis. Dalam fungsi sosialnya BMT Al-Hamasah lebih mengarah pada usaha-usaha pengumpulan dan penyaluran dana non-profit seperti zakat, infak, shodaqoh dan wakaf. Sementara fungsi bisnis tertuju pada usaha pengumpulan dan penyaluran dana komersil atau bisnis. Usaha-usaha tersebut menjadi bagian yang tidak terpisahkan dari BMT sebagai lembaga keuangan mikro dan sebagai salah satu pendukung berkembangnya pelaku ekonomi mikro dan kecil yang berlandaskan syariah.

\section{Penerapan Prinsip Syariah dalam Prodak Jasa yang Ditawarkan Kepada Masyarakat.}

Kehadiran BMT Al-Hamasah Kotaraja Lombok Timur dianggap sebagai jembatan untuk menghidupkan usaha-usaha skala kecil dengan pembiayaan yang tidak terlalu besar. Mengingat Negara Indonesia masih berstatus sebagai Negara berkembang yang butuh modal sangat besar untuk menggerakkan perekonomian menjadi lebih produktif di sektor riil (usaha mikro dan kecil), kehadiran BMT Al-Hamasah diharapkan lebih produktif di sektor pembiayaan dan pemberdayaan kepada masyarakat yang sulit dalam mengakses pembiayaan dari lembaga jasa keuangan besar seperti perbankan konvesional maupun dari perbankan syariah yang ada.

BMT Al-Hamasah Kotaraja Lombok Timur memastikan dan menjamin penerapan prinsip syariah dalam setiap produk jasa yang ditawarkan kepada masyarakat, maka BMT Al-Hamasah sebagai badan hukum Koperasi, memiliki struktur organisasi sebagaimana lazimnya pada badan usaha koperasi yaitu seperti Rapat Anggota, Pengurus, Pengawas dan sesuai dengan aturan yang terbaru harus memiliki organ tambahan yaitu Dewan Pengawas Syariah (DPS) yang bertugas mengawasi apakah BMT Al-Hamasah dalam melakukan kegiatan usahanya tersebut telah melakukan kegiatan usaha sesuai dengan prinsip syariah atau tidak, hal ini sengat prinsip karena jangan sampai terjadi dalam Anggaran Dasar dan Anggaran Rumah Tangga (AD/ART) BMT yang notabene dalam operasinalisasinya menggunakan prinsip syariah, namun dalam kenyataannya tidak memperhatikan bahkan tidak menerapkan prinsip syariah terhadap produk jasa yang dimilikinya.

Sesuai dengan Undang-Undang Nomor 25 Tahun 1992 tentang Perkoperasian, bahwa anggota koperasi adalah pemilik sekaligus sebagai pengguna jasa koperasi (BMT). Oleh karenanya Rapat Anggota (BMT) merupakan kekuasaan tertinggi dalam lembaga koperasi, keanggotaan diatur dalam Anggaran Dasar dan Anggaran Rumah Tangga Koperasi (BMT). Keanggotaan koperasi melekat pada diri anggota sendiri dan tidak dapat dipindahkan kepada orang lain dengan dalih apapun. Setiap anggota harus tunduk kepada ketentuan dalam AD/ART Koperasi sebagai peraturan khusus dan terhadap keputusan-keputusan Rapat Anggota lainnya. 
Sementara Pengurus Koperasi (BMT) diangkat oleh anggota dalam Rapat Anggota yang diselenggarakan untuk kepentingan pengangkatan pengurus atau dilaksanakan bersamaan dengan kegiatan Rapat Anggota Tahunan (RAT) BMT. Pengurus adalah penerima amanat anggota untuk menjalankan organisasi dan usaha koperasi (BMT) dengan berlandasakan pada Rencana Kerja dan Rencana Anggaran Pendapatan Belanja (RK-RAPB) yang diputuskan atau ditetapkan dalam rapat anggota. Jumlah anggota pengurus sedikitnya terdiri dari tiga orang yaitu ketua, sekretaris dan bendahara sesuai dengan angaran dasar koperasi (BMT), masa jabatan pengurus sesuai dengan yang diatur dalam anggaran dasar, bisa dua, tiga, empat atau lima tahun. Pengurus harus dipilih dari atau oleh anggota dan bertanggung jawab kepada anggota dalam rapat anggota.

Adapun pengawas, sesuai dengan Pasal 21 Undang-Undang Nomor 25 Tahun 1992 bahwa perangkat koperasi (BMT) terdiri; Rapat Anggota, Pengurus dan Pengawas. Dengan demikian keberadaan pengawas koperasi benar-benar diakui disamping merupakan satu diantara tiga perangkat organisasi. Pengawasan koperasi dilakukan oleh pengawas yang diangkat dari dan oleh anggota dalam rapat anggota sekaligus bertanggung jawab kepada anggota. Pengawas melaksanakan pengawasan paling tidak sebulan sekali yaitu pada saat laporan keuangan bulanan yang dilakukan oleh manager dihadapan pengawas dan pengurus sehingga jika ada kejanggalan dalam aktivitas dan usaha atau keuangan, maka pengawas dapat memberikan arahan dan bahkan untuk menindak lanjutinya.

Kemudian berdasarkan Peraturan Menteri Negara Koperasi dan Usaha Kecil dan Menengah Republik Indonesia Nomor 35.2/Per/M.KUKM/X/2007, tugas pokok Dewan Pengawas Syariah di BMT ada 3 macam yaitu : 1). Mengesahkan dan mengembangkan produk BMT, yaitu melakukan telaah kritis terhadap akad yang telah dipergunakan, memperbaikinya agar sesuai dengan prinsip syariah. Begitu pula dengan mengkaji dan mempelajari fatwa DSN-MUI untuk melihat kemungkinan penterjemahannya menjadi produk bari di BMT. 2). Mengawasi manajemen BMT dalam mengapliksikan akad yaitu melakukan pengawasan operasional kerja, manajemen dan aplikasi akad, baik antar pengurus, pengelola mupun pihak luar yang berhubungan dengan BMT. 3). Membina pengurus dan pengelola BMT secara informal melalui interaksi keseharian, rapat pengurus, maupun secara formal dan rutin dalam kajian tausiah yang memberikan bekal dan pemahaman keislaman yang menyeluruh.

Dalam kenyataan operasional BMT masih sering dijumpai indikasi penyimpangan dari prinsip syariah. Beberapa BMT ditengarai masih menggunakn sistem bunga walaupun istilah yang digunakan dalam akadakadnya menggunakan Bahasa Arab. Terdapat akad-akad yang terindikasi begitu dekat dan hampir sama dengan akad di lembaga keuangan konvensional dan perbedaannya hanya dri segi istilah semata. Hal ini yang menyebabkan sebagian masyarakat beranggapan tidak ada perbedaan antara BMT dengan lembaga keuangan konvensional karena dalam praktek yang mereka lihat sama saja antara keduanya, bahkan ada sebagian masyarakat yang menolak untuk menggunakan jasa atau produk BMT karena belum sepenuhnya syariah dalam kegiatan usahanya.

Bentuk-bentuk penyimpangan semacam ini harus diminimalisir bahkan dihilangkan sama sekali dari BMT, BMT harus menyadari bila hal ini terjadi, maka akan menghadapi risiko reputasi yang bermuara pada kekecewaan masyarakat sekaligus merusak citra dan bahkan dapat mendatangkan dosa. Apabila penyimpangan-penyimpangan di atas disebabkan kurang maksimalnya pengawasan Dewan Pengawas Syariah (DPS) karena minimnya tingkat pemahamannya tentang operasional BMT, maka pengangkatan dan penempatannya untuk kedepan harus memperhatikan kompetensi dan tidak lagi hanya menghandalkan kharisma dan kepopulerannya di tengah masyarakat.

Sesunguhnya tugas mengawasi dan mengarahkan lembaga-lembaga keuangan syariah adalah tugas dari Dewan Syariah Nasional Majelis Ulama Indonesia yang berkedudukan di Jakarta. Namun, karena keterbatasan jumlah anggota dan jumlah lembaga keuangan syariah semakin bertambah banyak yang tersebar di seluruh wilayah Negara Kesatuan Republik Indonesia, sehingga pengawasannya diserahkan kepada Dewan Pengawas Syariah. DPS berkewajiban secara langsung melihat pelaksanaan suatu lembaga keuangan syariah agar tidak menyimpang dari ketentuan yang telah difatwakan oleh DSN. DPS melihat secara garis besar dari aspek manajemen dan administrasi harus sesuai dengan syariah, dan yang paling utama sekali mengesahkan dan mengawasi produk-produk lembaga keuangan syariah agar sesuai dengan ketentuan syariah dan undang-undang yang berlaku.

\section{PENUTUP}

\section{Simpulan}

Berdasarkan apa yang telah diuraikan pada pembahasan di atas, maka dapat disimpulkan bahwa :

1. Legalitas yang harus dipenuhi oleh Badan Usaha Mandiri Terpadu (BMT) sebagai lembaga keuangan mikro berdasarkan hukum di Indonesia yaitu Pertama, harus berbentuk Badan Hukum, baik badan 
hukum Perseroan Terbatas (PT) maupun berbentuk Koperasi dengan mengikuti prosedur dan memenuhi persyaratan yang ditentukan dalam Undang-Undang Perseroan Terbatas dan Perkoperasian yang berlaku terutama dalam pendiriannya; Kedua, BMT wajib memiliki Akta Pendirian yang dibuat dan dihadapan Notaris atau dalam bentuk Akta Notaris; Ketiga, BMT wajib memiliki izin usaha dari instansi terkait, baik BMT serba usaha ataupun yang bergerak dalam bidang usaha simpan pinjam; Keempat, BMT wajib memiliki Nomor Pokok Wajib Pajak dengan demikian, maka secara otomatis akan menjadi subyek hukum yang dapat dikategorikan wajib pajak; Kelima, BMT wajib memiliki Tanda Daftar Perusahaan (TDP), hal ini sesuai dengan ketentuan perundang-undangan yang berlaku di Indonesia yaitu setiap kegiatan usaha yang melakukan kegiatan usaha di wilayah Negara Kesatuan Republik Indonesia, kecuali bagi kegiatan usaha yang dikecualikan, diwajibkan untuk memiliki Tanda Daftar Perusahaan.

2. Produk jasa yang disediakan oleh BMT Al-Hamasah dalam pelayanan kepada masyarakat lebih mengarah pada usaha-usaha pengumpulan dan penyaluran dana non-profit seperti zakat, infak, shodaqoh dan wakaf. Sementara fungsi bisnis tertuju pada usaha pengumpulan dan penyaluran dana komersil atau bisnis yang dapat berupa; a). jual beli, baik murabahah, salam dan istishna; b). Bagi Hasil, baik dalam penghimpunan dana (funding) dalam berntuk simpanan dan penyaluran dana (lending) dalam bentuk produk penyaluran dana yaitu produk pembiayaan mudharabah dan musyarakah; dan c). Pinjam meminjam atau qardh, yaitu pinjam meminjam dana tanpa imbalan dan ada juga qordh al-hasan (pinjaman kebajikan).

3. Penerapan prinsip syariah terhadap produk jasa yang ditawarkan kepada masyarakat, maka BMT AlHamasah sebagai badan hukum Koperasi, memiliki struktur organisasi lazimnya pada koperasi lainnya yaitu Rapat Anggota, Pengurus, Pengawas dan sesuai dengan aturan yang terbaru harus memiliki organ tambahan yaitu Dewan Pengawas Syariah (DPS) yang bertugas memastikan, menjamin dan mengawasi apakah semua produk jasa serta kegiatan BMT Al-Hamasah sebagai lembaga keuangan mikro telah berjalan dan sesuai dengan prinsip syariah dan undang-undang yang berlaku.

\section{Saran}

1. Badan Usaha Mandiri Terpadu (BMT) sebagai lembaga keuangan mikro ketika didirikan dan dalam harus memenuhi legalitas berdasarkan hokum di Indonesia.

2. Penerapan prinsip syariah terutama dalam produk jasa yang di tawarkan kepada masyarakat harus memperhatikan prinsip syariah berdasarkan perundang-undangan.

\section{DAFTAR PUSTAKA}

Abdul Rasyid. (2018). Perkembangan Lembaga Perbankan dan Keuangan Syariah di Indonesia, Business-law.binus.ac.id.

Kuntowijoyo. (2001). Seputar Perkembangan Sejarah Umat Dalam Muslim Tanpa Masjid. Bandung: Mizan Keputusan Menteri Keuangan Nomor. 468/KMK.017/1995 tentang Ketentuan dan Tata Cara Pelaksanaan Lembaga Pembiayaan.

Peraturan Presiden No. 9 Tahun 2009 tentang Lembaga Pembiayaan

Peraturan Otoritas Jasa Keuangan Nomor 12/POJK.05/2014 tentang Perizinan Usaha dan Kelembagaan Lembaga Keuangan Mikro

Undang-Undang Nomor 1 tahun 2013 Tentang Lembaga Keuangan Mikro

Undang-Undang Nomor 25 Tahun 1992 Jo Undang-Undang Nomor 17 t ahun 2012 Tentang Perkoperasian

Undang-Undang Nomor 7 Tahun 1992 Jo Undang-Undang Nomor 10 tahun 1998 tentang Perbankan

Undang-Undang Nomor 3 Tahun 1982 tentang Wajib Daftar Perusahaan 